\title{
A Novel Class of Ectomycorrhiza-Regulated Cell Wall Polypeptides in Pisolithus tinctorius
}

\author{
Pascal Laurent, ${ }^{1}$ Catherine Voiblet, ${ }^{1}$ Denis Tagu, ${ }^{1}$ Dulcinéia de Carvalho, ${ }^{1}$ Uwe Nehls, ${ }^{1}$ \\ Roberta De Bellis, ${ }^{1}$ Raffaella Balestrini, ${ }^{2}$ Guy Bauw,${ }^{3}$ Paola Bonfante,${ }^{2}$ and Francis Martin ${ }^{1}$ \\ ${ }^{1}$ Equipe de Microbiologie Forestière, Centre de Recherches de Nancy, Institut National de la Recherche

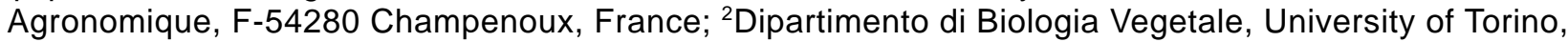 \\ Viale Mattioli, 25-10125 Torino, Italia; ${ }^{3}$ Rijkuniversiteit Gent, Laboratorium Genetika, Ledeganckstraat \\ 35, B-9000 Gent, Belgium \\ Accepted 2 June 1999.
}

\begin{abstract}
Development of the ectomycorrhizal symbiosis leads to the aggregation of fungal hyphae to form the mantle. To identify cell surface proteins involved in this developmental step, changes in the biosynthesis of fungal cell wall proteins were examined in Eucalyptus globulus-Pisolithus tinctorius ectomycorrhizas by two-dimensional polyacrylamide gel electrophoresis. Enhanced synthesis of several immunologically related fungal 31- and 32-kDa polypeptides, so-called symbiosis-regulated acidic polypeptides (SRAPs), was observed. Peptide sequences of SRAP ${ }_{32 d}$ were obtained after trypsin digestion. These peptides were found in the predicted sequence of six closely related fungal cDNAs coding for ectomycorrhiza up-regulated transcripts. The PtSRAP32 cDNAs represented about $10 \%$ of the differentially expressed cDNAs in ectomycorrhiza and are predicted to encode alanine-rich proteins of $28.2 \mathrm{kDa}$. There are no sequence homologies between SRAPs and previously identified proteins, but they contain the ArgGly-Asp (RGD) motif found in cell-adhesion proteins. SRAPs were observed on the hyphal surface by immunoelectron microscopy. They were also found in the host cell wall when $P$. tinctorius attached to the root surface. RNA blot analysis showed that the steady-state level of PtSRAP32 transcripts exhibited a drastic up-regulation when fungal hyphae form the mantle. These results suggest that SRAPs may form part of a cell-cell adhesion system needed for aggregation of hyphae in ectomycorrhizas.
\end{abstract}

Additional keywords: differentiation, fungus.

The development of the ectomycorrhizal symbiosis involves specific cell-cell and cell-substrate interactions that direct the extension of hyphae to their precise host root targets. As the outer part of the hyphal element, the cell wall mediates the ini-

Corresponding author: F. Martin, Equipe de Microbiologie Forestière, Centre de Recherches I.N.R.A. de Nancy, 54280 Champenoux, France; Telephone: +33 3833940 80; Fax: +33 3833940 69; E-mail: fmartin@ nancy.inra.fr

Nucleotide and/or amino acid sequence data are to be found at the GenBank data base as accession nos. AF035678, AF124722, AF124723, and AF124724.

Pascal Laurent and Catherine Voiblet contributed equally to this work. tial physical interactions between the hyphae and the environment, including the host. A role for fungal cell walls in symbiosis development is supported by the observed alterations in cell wall composition (Dexheimer and Pargney 1991; Peterson and Bonfante 1994; Tagu and Martin 1996; Martin et al. 1997, in press). Major aspects of the ectomycorrhiza formation involving cell walls and the extracellular matrix are the adhesion of fungal cells to host surface (Tagu and Martin 1996), the rapid formation of the symbiotic interface (Peterson and Bonfante 1994), and the modulation of the host defense responses (Salzer et al. 1997). The basis of these processes likely involves receptors on the hyphal tip that can recognize specific environmental cues in the extracellular matrix or on the surface of other cells. Several classes of cell adhesion molecules, such as hydrophobins and mannoproteins, have been suggested to play such a role in pathogenic fungi through the activation of intracellular signaling cascades and cytoskeletal changes (Mendgen and Deising 1993; Jones 1994; Dean 1997; Chaffin et al. 1998; Kershaw and Talbot 1998). In ectomycorrhizal fungi, only one family of proteins involved in adhesion and up-regulated during symbiosis formation has been characterized in detail; namely, the hydrophobins (Tagu et al. 1996, 1998).

In Eucalyptus globulus-Pisolithus tinctorius and E. grandis$P$. tinctorius associations, two-dimensional polyacrylamide gel electrophoresis (2D-PAGE) analyses of total proteins have shown that several polypeptides in the 30 to $37 \mathrm{kDa}$ range, named symbiosis-regulated acidic polypeptides (SRAPs), accumulate during the early stages of the infection process (Hilbert et al. 1991; Burgess et al. 1995). Considering this early accumulation, we have suggested that SRAPs may correspond to fungal proteins secreted onto the root surface and/or components of the symbiotic extracellular matrix (Tagu and Martin 1996; Martin et al. 1997, in press). The isolation and characterization of these SRAPs and their corresponding genes should therefore provide an insight into the strategy adopted by ectomycorrhizal fungi to successfully colonize the root and drive the formation of symbiotic tissues. Using 2D-PAGE and differential screening of ectomycorrhiza transcripts, we showed that $31-$ and $32-\mathrm{kDa}$ SRAPs of $P$. tinctorius belong to a novel family of cell wall polypeptides that contain the Arg-Gly-Asp (RGD) motif common to cell-adhesion proteins (Gumbiner 1996). We have shown that these polypeptides are mostly located on the hyphal surface and their expression is up-regulated during symbiosis formation. 


\section{RESULTS}

\section{Characterization of abundant cell wall SRAPs.}

Up to 50 distinct polypeptides could be resolved by 2DPAGE of protein extracts of $P$. tinctorius 441 cell walls treated with hot sodium dodecyl sulfate (SDS)- $\beta$-mercaptoethanol (O'Farrell buffer; Fig. 1A). Most of the cell wall polypeptides (CWP) identified with silver stain could also be identified by ${ }^{35}$ S-amino acid labeling of hyphae (Tagu and Martin 1996), indicating that they are newly formed products of the fungus. Abundant acidic CWP were detected at 72 and $95 \mathrm{kDa}$ with additional prominent polypeptides between 30 and $32 \mathrm{kDa}$. Considering the enhanced accumulation of $32-\mathrm{kDa}$ polypeptides in the total protein (Hilbert et al. 1991) and cell wall (Fig. 1B and C) fractions of E. globulus-P. tinctorius ectomycorrhiza, we focused in this study on the set of $30-$ to $32-\mathrm{kDa}$ acidic polypeptides that consisted of nine polypeptides: $\mathrm{F}_{30 \mathrm{a}}$, $F_{30 b}, F_{30 c}, F_{31 a}, F_{31 b}, F_{32 a}, F_{32 b}, F_{32 c}$, and $F_{32 d}$. Peptide maps of the different $F_{31}$ and $F_{32}$ polypeptides, obtained after V8 protease digestion, were similar, with two digestion fragments at 14 and $17 \mathrm{kDa}$ (data not shown), suggesting that they correspond to various isoforms of a common (or related) polypeptide(s). In contrast, the $\mathrm{F}_{30}$ isopolypeptides did not share the same peptide map.

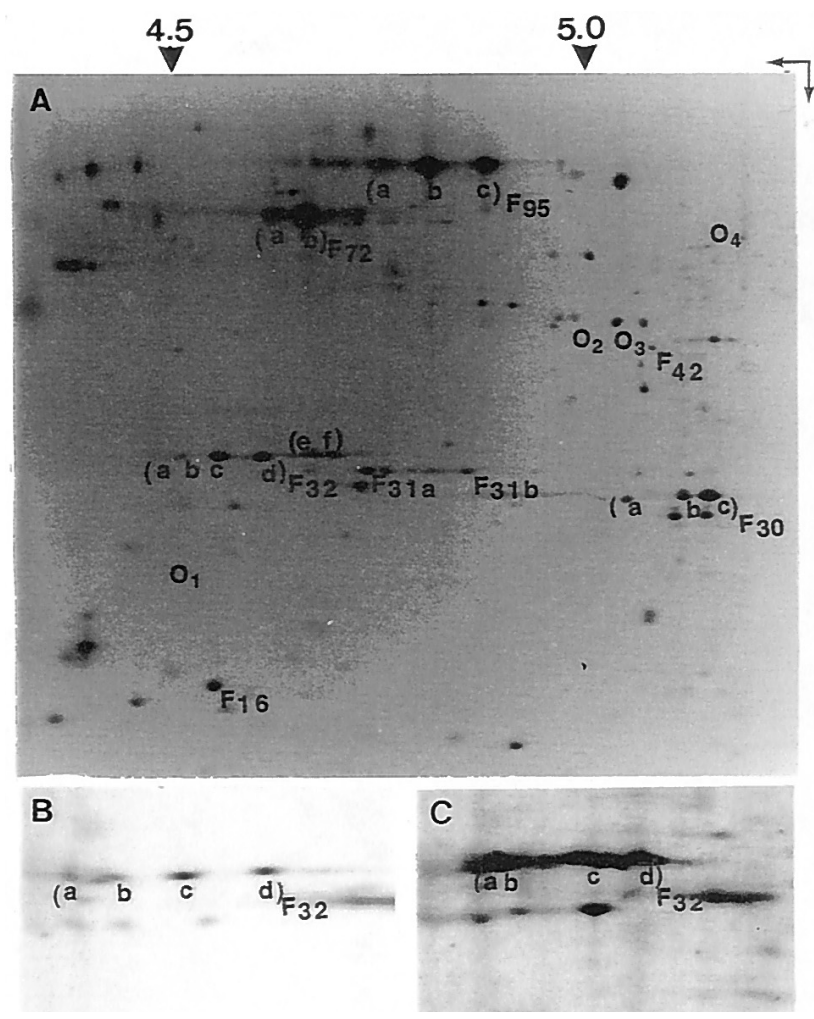

Fig. 1. A, Silver-stained two-dimensional (2-D) gels of purified cell wall proteins of Pisolithus tinctorius 441; B and C, Autoradiograms of 2Dgel areas highlighting a cluster of $31-$ and $32-\mathrm{kDa}$ of acidic polypeptides having an enhanced synthesis in Eucalyptus globulus-P. tinctorius ectomycorrhiza. B, Free-living mycelium. C, Four-day-old ectomycorrhizas. Subscripts denote molecular mass $(\mathrm{kDa})$ of polypeptides and are located at bottom right of protein spots. Open circles labeled 1, 2, 3, and 4 indicate position of the following Bio-Rad isoelectric point markers: soybean trypsin inhibitor ( $\mathrm{pI} 4.5,21.5 \mathrm{kDa})$, bovine muscle actin 1 ( $\mathrm{pI}$ $5.0,43 \mathrm{kDa}$ ), bovine muscle actin 2 (pI 5.1, $43 \mathrm{kDa}$ ), and bovine serum albumin (pI 5.5, 66.2 kDa), respectively. pI values are indicated on top.
The polypeptide $\mathrm{F}_{32 \mathrm{~b}}$, renamed $\mathrm{SRAP}_{32 \mathrm{~d}}$, which showed an enhanced synthesis in symbiotic tissues (Fig. 1C), was purified by 2D-PAGE and used to elicit antibodies in rabbit. Western blot (immunoblot) analysis with these antibodies confirmed that $\mathrm{SRAP}_{31}$ and $\mathrm{SRAP}_{32}$ isopolypeptides are closely related (Fig. 2). No immunologically related protein was detected in other ectomycorrhizal basidiomycetes (Fig. 2A).

The 31- and 32-kDa acidic polypeptides did not bind lectins, such as ConA and Galanthus nivalis agglutinin (GNA) (Laurent 1995; Tagu and Martin 1996). In vivo ${ }^{35}$ S-labeling of proteins and analysis of polypeptides secreted in the growth medium by one-dimensional (1D)-SDS-PAGE and 2D-PAGE (data not shown) showed that an isoform of the $32-\mathrm{kDa}$ acidic polypeptides, having a pI of 4.6, was secreted.

No N-terminal sequence information from purified $\mathrm{SRAP}_{32 \mathrm{~d}}$ was obtained, suggesting a blocked $\mathrm{N}$ terminus. It was then digested with trypsin. Following reversed-phase high-pressure liquid chromatography (HPLC), several fractions were re-

A

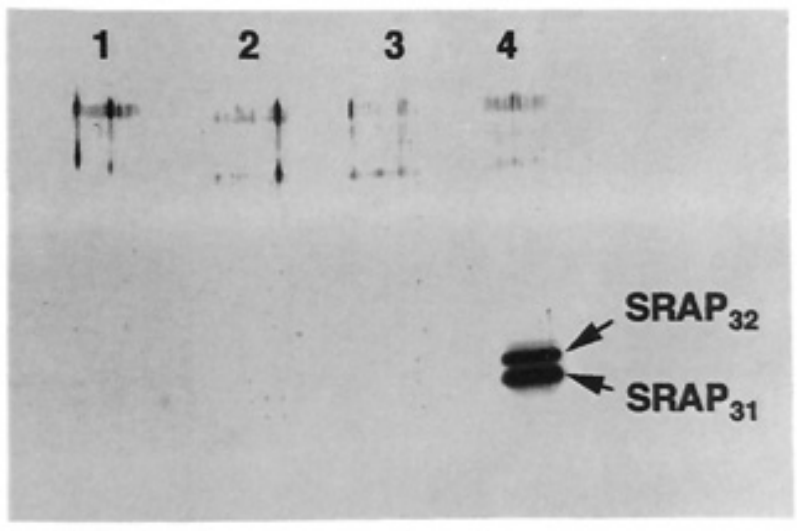

B

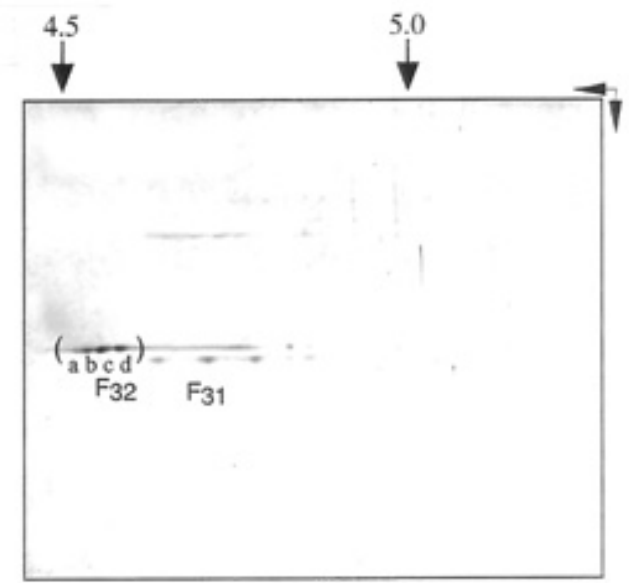

Fig. 2. A, Western blot (immunoblot) analysis of proteins extracted from cell walls of Pisolithus tinctorius and other ectomycorrhizal basidiomycetes probed with anti-SRAP $32 \mathrm{~d}$ polyclonal antibodies (1:1,000). Lane 1, Hebeloma cylindrosporum; lane 2, Boletus cavipes; lane 3, Amanita murina; lane 4, Pisolithus tinctorius 441. Arrowheads point to $\mathrm{SRAP}_{31}$ and $\mathrm{SRAP}_{32}$. B, Western blot analysis of proteins extracted from cell walls of $P$. tinctorius probed with anti-SRAP ${ }_{32 \mathrm{~d}}$ polyclonal antibodies $(1: 1,000)$. Two-dimensional polyacrylamide gel electrophoresis was performed as in Figure 1. 
solved from the proteolytic digest, and peptide sequences obtained (Table 1).

\section{Cloning of cDNAs encoding $\operatorname{SRAP}_{32}$.}

Because the synthesis of $\mathrm{SRAP}_{32 \mathrm{~d}}$ is up-regulated in the symbiosis (Fig. 1C), its oligopeptide sequences (Table 1) were searched in expressed sequence tags (ESTs) cloned from the ectomycorrhiza cDNA library with a cDNA mixture enriched in ectomycorrhiza up-regulated clones as a hybridization probe. This subtracted cDNA mixture was obtained by polymerase chain reaction (PCR)-based suppression subtractive hybridization (SSH) (Diatchenko et al. 1996). Within the 56 ESTs sequenced, six contained oligopeptide sequences from SRAP $_{32 \mathrm{~d}}$. In addition, these peptide sequences were also found in eight unknown clones within 528 cDNAs randomly picked from a non-enriched $E$. globulus-P. tinctorius ectomycorrhiza cDNA library (Martin and Voiblet 1998; C. Voiblet and F. Martin, unpublished results). Six cDNAs corresponding to

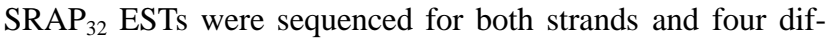
ferent amino acid sequences were found (Fig. 3). They contained the sequences of the oligopeptides derived from SRAP $_{32 \mathrm{~d}}$ (bold, Fig. 3) and were therefore named PtSRAP32-1 to 4 (AF035678, AF124722, AF124723, and AF124724). Most differences were located in the C-terminal part of the sequences. The predicted PtSRAP32 proteins have 261 amino acid residues $(28.2 \mathrm{kDa})$ and a $\mathrm{pI}$ ranging from 4.79 to 5.02 , as observed previously for the 31 - and $32-\mathrm{kDa}$ acidic polypeptides (Fig. 1A). The most abundant amino acids are Ala (13\%), Asp (9.6\%), Ser (8.8\%), and Glu (5.0\%). No similarity with known protein sequences was detected in the nonredundant National Center for Biotechnology Information (NCBI) data bases. No secretion signal was found. Interestingly, the predicted proteins contain the sequence RGD (Arg-Gly-Asp), a cell attachment sequence found on many adhesins (i.e., vitronectins, fibronectins), ligands of integrins (Gumbiner 1996). The RGD motif is located in a predicted hydrophilic loop domain of the protein.

\section{Localization of antigens recognized by anti-SRAP ${ }_{32 d}$ antibodies.}

To localize the PtSRAP32 proteins, indirect immunofluorescence (IIF) and immunogold transmission (EM) microscopies were performed on sections of free-living mycelium and ectomycorrhizas incubated with anti-SRAP ${ }_{32 \mathrm{~d}}$ antiserum or with pre-immune antiserum. For this study, 4-day-old ectomycorrhizas produced on primary roots (Malajczuk et al. 1990) and 15-day-old ectomycorrhizas produced on lateral roots (Burgess et al. 1996) were analyzed. Identical results were obtained on the two types of ectomycorrhizal roots. Freeliving mycelium, and inflated hyphae interacting with root

Table 1. Sequences of oligopeptides resulting from trypsin digestion of the cell wall SRAP $32 \mathrm{~d}$

\begin{tabular}{ll}
\hline Oligopeptides & Sequence \\
\hline pep 04 & A F F \\
pep 08 & T (D/G) V A N L L F A A R \\
pep 10 & A a G D Y I X G V \\
pep16 & F I D G Q T T G A a N F K \\
pep 19 & I L Q I G A F K \\
\hline
\end{tabular}

${ }^{a}$ Residues between parentheses are ambiguous and residues with a lowercase letter are questionable. hairs or aggregating to initiate the ectomycorrhizal sheath and the Hartig net, displayed an intense fluorescein labeling of their surface structures when incubated with the fluoresceinlabeled anti-SRAP ${ }_{32 \mathrm{~d}}$ antiserum (data not shown). This indicates that $\mathrm{SRAP}_{32 \mathrm{~d}}$ and immunologically related proteins are located in cell walls.

The walls of free-living mycelium (Fig. 4), and hyphae attaching to the root surface and penetrating between root cells (Fig. 5), were intensely labeled with the gold-labeled anti$\mathrm{SRAP}_{32 \mathrm{~d}}$ antiserum. The immunolabeling appeared to be homogeneous all around the cell periphery, showing no preferential site for the incorporation of the $\mathrm{SRAP}_{32}$ proteins. Gold labeling also was associated with the electron-dense material present in the vacuole (Fig. 4A). No labeling was detected with the control immunserum (Fig. 4D). Gold particles were often concentrated in the outer part of the cell walls and the electron-dense flocculent material covering them (Fig. 4B). In contrast, the fibrillar material accumulating between adjacent hyphae (Fig. 4C) and between hyphae and the root surface (Fig. 5D) was not labeled. Intense immunogold labeling of the fungal cell walls of hyphae attached to the mucigel covering the root surface (Fig. 5A-D) was observed. This clearly demonstrates that $\mathrm{SRAP}_{32}$ are abundantly synthesized at this stage. Interestingly, $\mathrm{SRAP}_{32}$ can be detected in the plant material where the electron-dense layer covering the mucigel was degraded (Fig. 5C). Finally, SRAP 32 antigens also accumulated in walls of dolipores (Fig. 5F) and transversal walls in hyphae of the Hartig net (Fig. 5E).

\section{Expression of PtSRAP ${ }_{32}$ during ectomycorrhiza development.}

RNA blot analysis was carried out to examine PtSRAP32 expression in $P$. tinctorius during eucalypt ectomycorrhiza formation (Fig. 6). Nucleotide divergence between PtSRAP32 sequences was not high enough to design transcript-specific DNA probes. With the PtSRAP32-1 cDNA probe, transcripts of approximately 900 nucleotides were detected only in the mycelium and not in roots. Formation of symbiotic tissues by P. tinctorius led to an enhanced accumulation of PtSRAP32 transcripts (Fig. 6A), confirming that this gene belongs to the family of symbiosis-regulated genes. Interestingly, PtSRAP32 transcripts were barely detectable during the initial stages of the interaction and displayed a sharp accumulation only 3 days after contact between symbionts when hyphae aggregate on the root surface to form the mantle. The concentration of PtSRAP32 transcripts was 10-fold higher in 7-day-old ectomycorrhiza, compared with the free-living mycelium. Control hybridization with a $P$. tinctorius-specific $5.8 \mathrm{~S}$ rRNA probe (Carnero Diaz et al. 1997), which is not affected by mycorrhiza development, was used to normalize the quantities of fungal mRNA present in each lane (Fig. 6).

\section{DISCUSSION}

Identification of the cell wall and cell surface proteins involved in fungal attachment and aggregation of hyphae ensheathing the roots is crucial to an understanding of how fungal hyphae establish early interactions with their host plant. Here, we showed that the protein composition of $P$. tinctorius cell walls is dramatically altered by development of the symbiosis. A novel class of 31- and 32-kDa SRAPs composed of 
at least six isoforms with different charge and/or molecular mass has been identified in cell wall extracts of Eucalyptus spp. $-P$. tinctorius ectomycorrhiza. The different isoforms share similar peptide maps and are immunologically related (Fig. 2). The 32-kDa SRAPs preferentially accumulated in fungal cell walls during early stages of E. globulus-P. tinctorius interaction (Fig. 1C). They share their electrophoretic properties ( $\mathrm{pI}$ and molecular mass) with ectomycorrhizins $\mathrm{E}_{32 \mathrm{a}}$ and $\mathrm{E}_{32 \mathrm{~b}}$, previously detected in TCA-soluble protein fraction of E. globulus-P. tinctorius 441 mycorrhiza (Hilbert et al. 1991) and soluble SRAPs found in E. grandis-P. tinctorius ectomycorrhiza (Burgess et al. 1995). Polypeptides recognized by anti-SRAP ${ }_{32 \mathrm{~d}}$ antiserum in hyphal vacuoles (Fig. 4A) may correspond to these previously reported soluble ectomycorrhizins (Hilbert et al. 1991).
Immunogold labeling confirmed that antigens immunologically related to $\mathrm{SRAP}_{32 \mathrm{~d}}$ are localized in cell walls of the freeliving and symbiotic hyphae (Figs. 4 and 5). These proteins could be found associated with the flocculent material covering the hyphal surface (Fig. 4B). In hyphae penetrating in the root, a $\mathrm{SRAP}_{32}$ antigen was found in direct contact with the plant material covering the host root wall, confirming that this protein could be secreted in the medium. Given the high antigen density required for visualization by IIF, the positive immunofluorescence of hyphae when tested with anti-SRAP ${ }_{32 \mathrm{~d}}$ antibodies indicates that $\mathrm{SRAP}_{32}$ are abundant antigens. Coupled with the strong signal intensity in Western blots (Fig. 2A) and RNA blots probed with PtSRAP32 cDNA (Fig. 6), these results indicate that $\mathrm{SRAP}_{32}$ are major hyphal surface proteins. Cross-reacting proteins were also detected in vacuoles (Fig. 4A) and dolipores

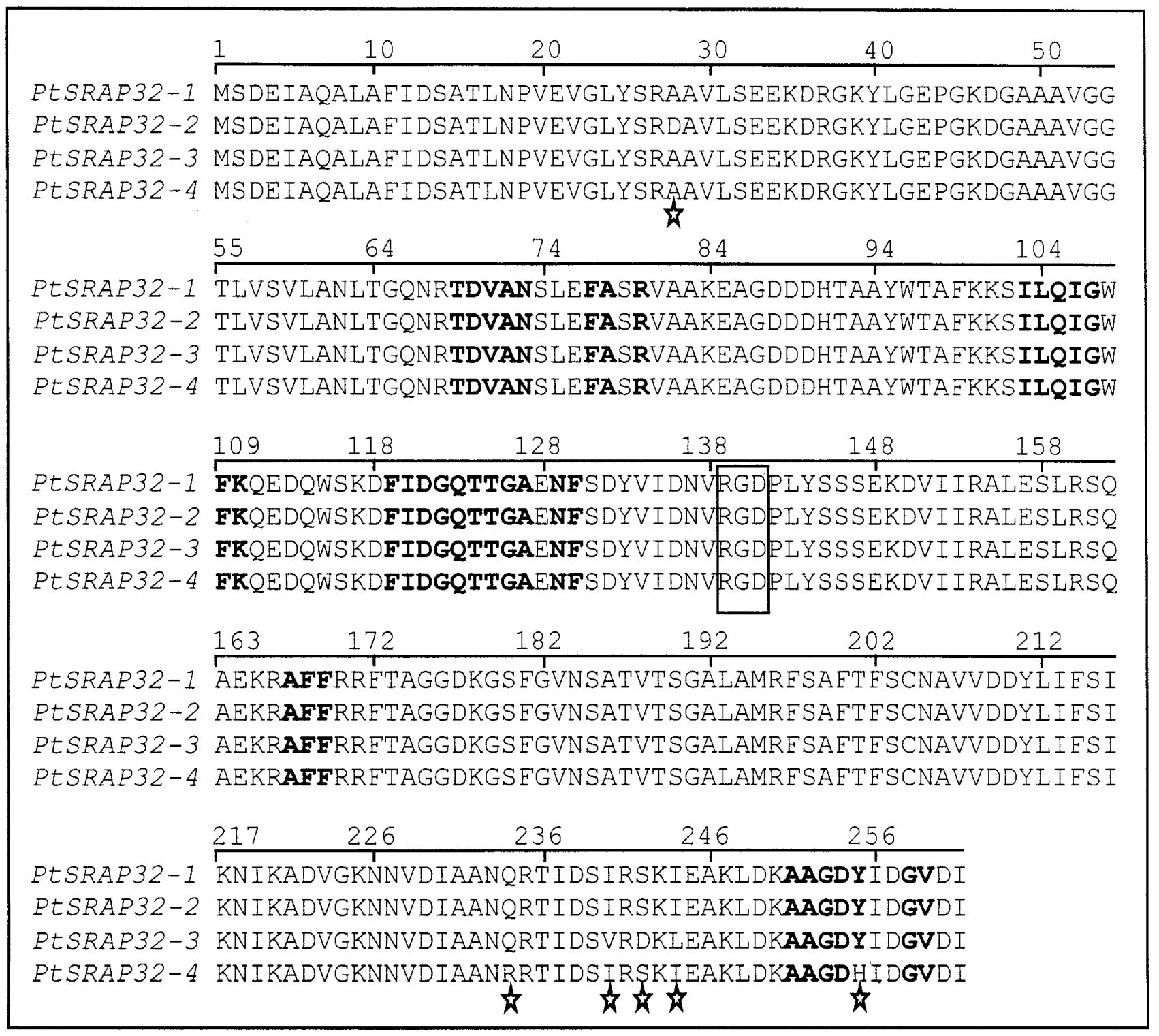

Fig. 3. Multiple alignment of deduced protein product from four different PtSRAP32 cDNAs (GenBank accession nos. AF035678, AF124722, AF124723, and AF124724). Amino acids are given in single-letter code. Alignment was perfomed by CLUSTAL V. Amino acid residues found in the $\mathrm{SRAP}_{32 \mathrm{~d}}$ oligopeptide sequences (Table 1) are indicated in bold type. A putative cell adhesion motif RGD is boxed. Unmatched amino acid residues are indicated by a star underneath the sequence. 
(Fig. 5F), suggesting that the different $\mathrm{SRAP}_{32}$ isoforms may have different roles in the fungal cell (see below).

Fourteen ESTs encoding $\mathrm{SRAP}_{32}$-related proteins have been cloned by differential screening and random sequencing in $E$. globulus $-P$. tinctorius mycorrhiza. The predicted proteins contained the oligopeptide sequences from $\mathrm{SRAP}_{32 \mathrm{~d}}$ (Fig. 3), although minor sequence differences could be detected between the four different proteins identified. The PtSRAP32
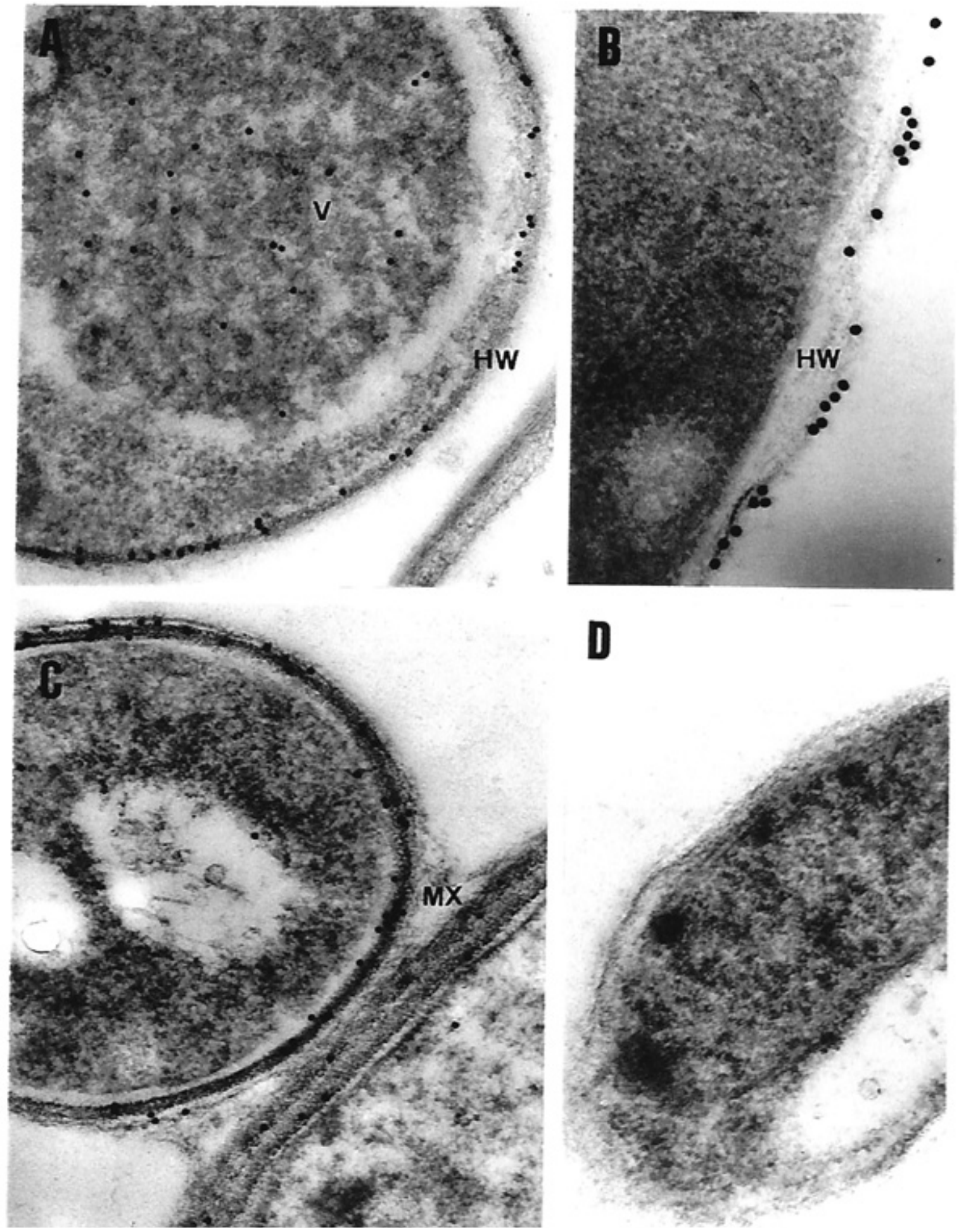

Fig. 4. Immunogold labeling with anti-SRAP $32 \mathrm{~d}$ antibodies $(1: 1,000)$ of free-living mycelium of Pisolithus tinctorius. A, Cross section of a fungal hypha. Labeling is located in the fungal cell wall (HW) and electron-dense material present in the vacuole (V) $(\times 58,000)$. B, Higher magnification of an area showing SRAP $_{32 \mathrm{~d}}$ and immunologically related polypeptides on cell wall surface $(\times 100,000)$. C, Cross section of attached fungal hyphae. Labeling is located in the fungal cell wall, but is not detected in the extracellular fibrillar matrix (MX) between the hyphal walls $(\times 58,000)$. D, Absence of labeling in the control with pre-immunserum $(\times 58,000)$. 
cDNAs predicted $28.2-\mathrm{kDa}$ proteins without an N-terminal secretion signal (Fig. 3). Sequence analysis of $\mathrm{SRAP}_{32}$ showed no significant homology with known proteins in data bases, but revealed a high content in alanine (13\%). Alanine- rich proteins have been reported in cell walls of Pythium spp. (Takenaka and Kawasaki 1994). The central part of the deduced $\mathrm{SRAP}_{32}$ proteins contains an Arg-Gly-Asp (RGD) motif. The RGD motif was first discovered in fibronectin as a
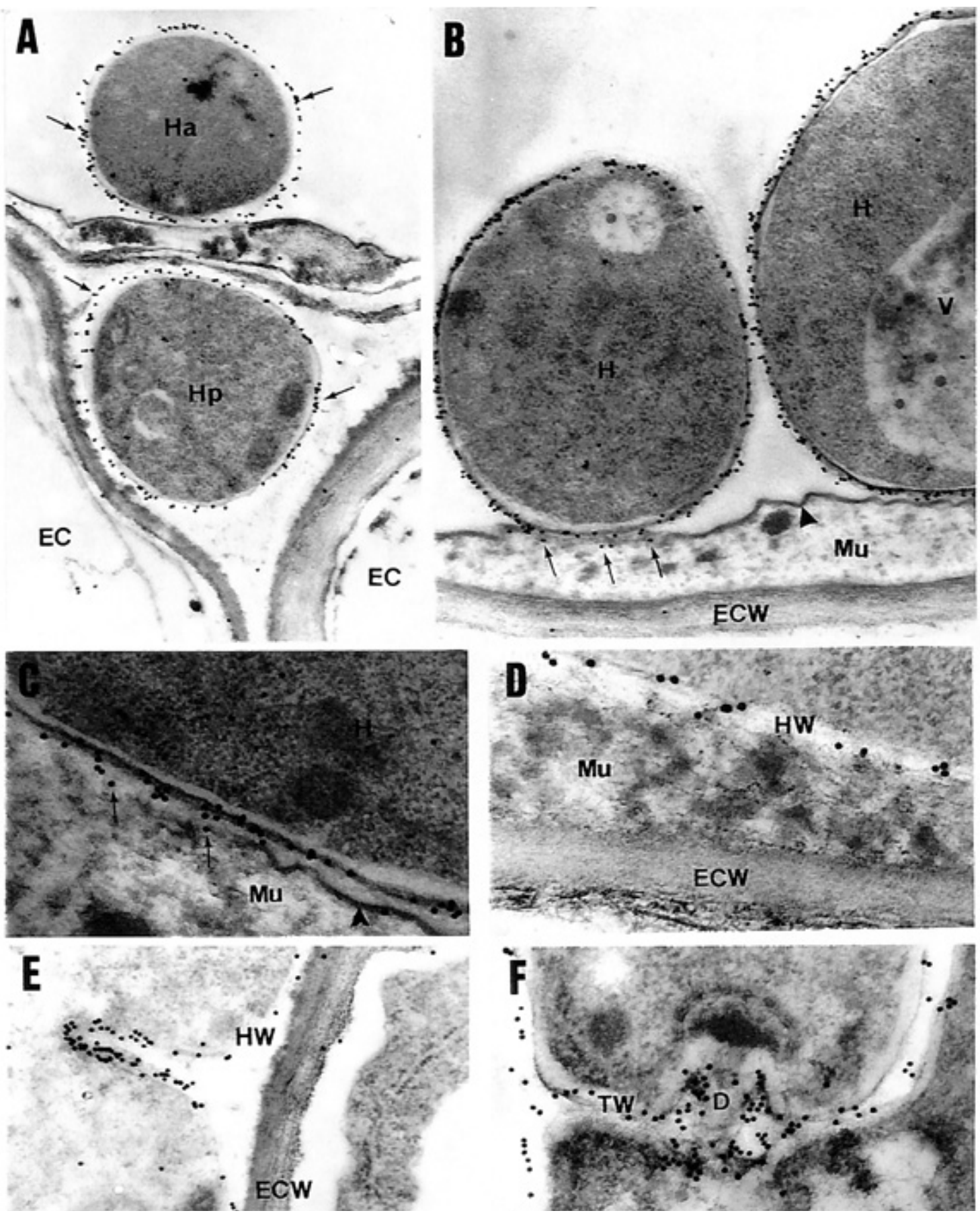

Fig. 5. Immunogold labeling with anti-SRAP ${ }_{32 \mathrm{~d}}$ antibodies of Pisolithus tinctorius colonizing eucalypt roots. A, Cross section of fungal hyphae attaching to the root surface (Ha) and penetrating between host root cells (Hp). Intense labeling is located in fungal cell wall (arrows). Remnants of an epidermal cell is present between the two fungal hyphae $(\times 58,000)$. B. Hyphae contacting the host epidermal cell wall (ECW). Extracellular mucilage $(\mathrm{Mu})$ is covered by a thin electron dense layer (thick arrowhead). Labeling is found in this mucilage where the thin electron dense layer is degraded (arrows) $(\times 30,000)$. C, Higher magnification of contact area. Fungal wall is strongly labeled and thin electron dense layer (thick arrowhead) is lacking $(\times 58,000)$. D, Higher magnification of another contact area. Labeling is located in the fungal cell wall, but is not detected in the extracellular fibrillar matrix between the hyphal walls and the root surface $(\times 58,000)$. E, Higher magnification of an area showing formation of a transversal fungal wall and a dense accumulation of $\mathrm{SRAP}_{32 \mathrm{~d}}$ antigens $(\times 58,000)$. F, Higher magnification of a fungal septum showing an intense labeling of the transversal walls (TW) and dolipore (D) $(\times 58,000)$ 
cell attachment site and was subsequently found to be the recognition sequence for a number of integrin receptors (Ruoslahti 1996). It has been reported in fungi (see Dean 1997 for a review) and plants (Canut et al. 1998; Faik et al. 1998). RGD-containing peptides inhibit thigmotropically induced cell differentiation in Uromyces appendiculatus (Corrêa et al. 1996). The ectopic expression of the RGD-containing MFBAC protein found in the mushroom Lentinus edodes (Kondoh et al. 1995) is able to induce flocculation in yeast (Yasuda and Shishido 1997) and aggregation of Schizophyllum commune hyphae (Yasuda et al. 1997). However, demonstration of the functionality of $\mathrm{SRAP}_{32}$ as a ligand on integrin-like proteins remains to be achieved. Production in E. coli of the recombinant $\mathrm{SRAP}_{32}$ polypeptide has been attempted with different vectors (pET, pGEX...), but has failed so far.

One of the most interesting features of PtSRAP32 genes is their developmentally regulated expression in eucalypt ectomycorrhiza. The steady-state level of PtSRAP32 transcripts is several-fold higher in fungal tissues in planta than in free-living mycelium. Concentration of PtSRAP32 transcripts is barely detectable during the early stages of mycorrhiza formation and mostly accumulates 3 days after contact when the ectomycorrhizal sheath is aggregating around the colonized roots and the infecting hyphae penetrate between the epidermal cells. The presence of PtSRAP32 mRNA correlates with the expression of the $\operatorname{SRAP}_{32 \mathrm{~d}}$ (Fig. 1C) and ectomycorrhizin $\mathrm{E}_{32 \mathrm{a}}$ and $\mathrm{E}_{32 \mathrm{~b}}$ (Hilbert et al. 1991; Burgess et al. 1995), suggesting that some PtSRAP32 are encoding 32-kDa ectomycorrhizins.

Although we showed in previous work that ectomycorrhiza formation alters protein biosynthesis (Hilbert et al. 1991; Burgess et al. 1995), the mechanisms contributing to the expression of SR proteins were not determined. The present finding that control of expression of $\mathrm{SRAP}_{32}$ was mediated by mRNA levels suggests that synthesis of new proteins is an important process in controlling hyphal surface gene expression during symbiosis formation. Up-regulation of CWP synthesis in eucalypt ectomycorrhiza is not limited to SRAPs. Transcripts of three different hydrophobins, another class of fungal secreted cell wall proteins (Wessels et al. 1991), similarly accumulate several-fold in $P$. tinctorius hyphae colonizing the eucalypt root surface (Tagu et al. 1996).

CWP are known to form cross-linked networks with other proteins and polysaccharides in fungal walls (Ruiz-Herrera et al. 1994; Chaffin et al. 1998), but the structural properties and the functional significance of such networks are not yet

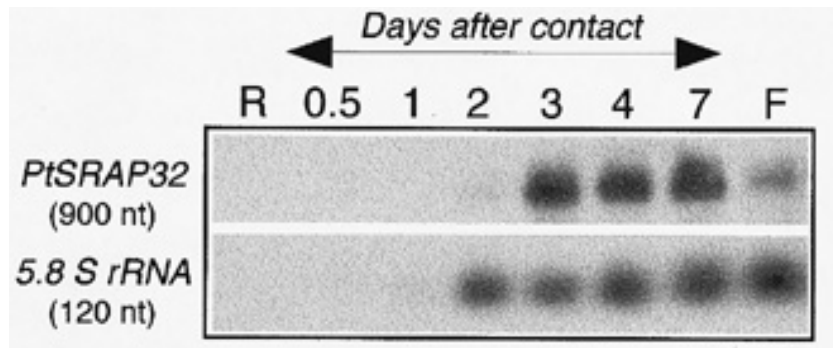

Fig. 6. Steady-state level of PtSRAP32 transcripts in noninoculated Eucalyptus globulus roots (R), roots colonized by Pisolithus tinctorius $(0.5,1,2,3,4$, and 7 days after contact) and free-living $P$. tinctorius 441 (F) determined by RNA blotting. Filter was hybridized with the ${ }^{32} \mathrm{P}-$ labeled PtSRAP32-1 probe (upper part). The same filter was rehybridized with the $P$. tinctorius-specific $5.8 S$ rDNA probe (lower part). known. Perhaps high levels of up-regulated $\mathrm{SRAP}_{32}$ (this study), down-regulation of the mannoprotein gp95 (Laurent 1995; Tagu and Martin 1996), and increased levels of hydrophobic proteins (Tagu et al. 1996) function simultaneously to regulate the molecular architecture of protein networks in a manner that allows new developmental fates for both fungal cell adhesion and root colonization by the fungus (Jones 1994; Dean 1997; Chaffin et al. 1998). Further investigation of the structure and regulation of SR wall proteins will provide a more complete picture of their role in developing ectomycorrhizal tissues.

\section{MATERIALS AND METHODS}

\section{Fungus and plant growth and aseptic synthesis of ectomycorrhizas.}

Cultures of $P$. tinctorius 441 (Pers.) Coker \& Couch (syn.: P. arhizus (Scop. per Pers.) Rauschert), Hebeloma cylindrosporum 331, Boletus cavipes BESS, and Amanita muscaria 42 were maintained on modified Pachlewski's medium (20 g . liter $^{-1}$ glucose, $2 \% \mathrm{wt} / \mathrm{vol}$ agar) (Hilbert et al. 1991). Seeds of E. globulus subsp. bicostata (Maid et al.) Kirkp. were pretreated and germinated, and seedlings grown as previously described (Hilbert et al. 1991), except a low glucose (1 g . liter $^{-1}$ ) Pachlewski's agar medium was used. On day 7, seedlings were used for aseptic synthesis of $P$. tinctorius $-E$. globulus ectomycorrhizas by the cellophane-over-agar method (Malajczuk et al. 1990), modified as described by Hilbert et al. (1991) and Burgess et al. (1996), except that the low glucose Pachlewski's medium was used. Free-living mycelium (1 $\mathrm{cm}$ edge of the colony), and ectomycorrhizal and noninoculated seedlings were sampled, frozen in liquid $\mathrm{N}_{2}$, and stored at $-20^{\circ} \mathrm{C}$. Excess extramatrical mycelium was excised from ectomycorrhizas prior to freezing.

\section{In vivo labeling of proteins.}

Free-living mycelium and ectomycorrhizal and noninoculated seedlings were labeled in vivo by immersion of roots or mycelium in sterile low glucose Pachlewski's solution containing ${ }^{35} \mathrm{~S}$-cell labeling mix (70\% methionine, 30\% cysteine, $11 \mathrm{Mbq} \mathrm{ml}^{-1}$; Amersham, Les Ulis, France) according to Burgess et al. (1995). For labeling of secreted fungal proteins, fungal colonies of $P$. tinctorius 441 ( $2 \mathrm{~g}$ wet weight) were floated over $2 \mathrm{ml}$ of growth medium containing $11 \mathrm{Mbq} \mathrm{ml}^{-1}$ ${ }^{35} \mathrm{~S}$-cell labeling mix for $16 \mathrm{~h}$. Proteins secreted into growth medium were precipitated by making the medium up to $5 \%$ (wt/vol) in TCA and incubating for $1 \mathrm{~h}$ on ice. After centrifugation $(14,000 \times g, 30 \mathrm{~min})$, the precipitate was washed twice with $5 \%$ TCA, dissolved in SDS- or 2D-PAGE buffer, and subjected to electrophoresis.

\section{Protein extraction and isolation of CWP.}

Approximately 30 root systems from ectomycorrhizal and noninoculated seedlings and about $50 \mathrm{mg}$ of free-living mycelium were use for each protein extraction. Soluble proteins were extracted by the phenol method as described by Burgess et al. (1995). The aqueous phase and the phenol/water interface containing cell debris were kept for the extraction of CWP.

Cell walls were recovered by mixing $800 \mu$ of the above mentioned aqueous phase containing cell debris with $800 \mu \mathrm{l}$ of 
$100 \mathrm{mM}$ Tris- $\mathrm{HCl}, \mathrm{pH} 8.0$, containing $10 \mathrm{mM} \mathrm{MgSO}_{4}$ and 1 $\mathrm{mM}$ phenylmethylsulfonyl fluoride and $0.2 \%$ (vol/vol) $\beta$ mercaptoethanol (buffer A) (Wessels et al. 1991). One micromolar leupeptin, $1 \mu \mathrm{M}$ pepstatin, and $100 \mu \mathrm{M}$ EDTA were added to prevent any protease degradation. The suspensions were then centrifuged for $15 \mathrm{~min}$ at $14,000 \times g$. Pellets containing walls were washed three times with $800 \mu$ of buffer A, twice with $800 \mu \mathrm{l}$ of water, once in $800 \mu \mathrm{l}$ of cold acetone, and dried. Absence of any cytoplasmic or organellar contaminations of the cell wall fraction was kindly assessed by transmission EM at the Electron Microscopy Facilities of the University of Nancy I by I. Le Disquet and J. C. Pargney. Noncovalently bound proteins were extracted from walls by incubation of $5 \mathrm{mg}$ of dried cell walls in either $50 \mu \mathrm{l}$ of O'Farrell's lysis buffer (O'Farrell 1975) at $50^{\circ} \mathrm{C}$ for $1 \mathrm{~h}$ (2DPAGE) or $100 \mu$ l of Laemmli's sample buffer (Laemmli 1970) at $100^{\circ} \mathrm{C}$ for $10 \mathrm{~min}$ (1D-SDS-PAGE). The protein content was determined by the Bradford method with the Bio-Rad protein assay as described by the manufacturer.

\section{PAGE.}

2D-PAGE of unlabeled and ${ }^{35} \mathrm{~S}$-labeled CWP was performed as described by Burgess et al. (1995), except ampholytes were added to the final concentration of $4 \%$ and consisted of $50 \%$ ampholytes pH 3.5 to 10 (Bio-Rad, Ivry-surSeine, France) and 50\% ampholytes pH 2.5 to 5 (Pharmacia, St. Quentin en Yvelines, France). Following electrophoresis, gels were silver stained (Hilbert et al. 1991) and gels of radiolabeled proteins immersed in the Amplify enhancing solution (Amersham, Les Ulis, France), dried onto a filter paper and autofluorographed onto Hyperfilm $\beta$-max (Amersham, Les Ulis, France) with Cronex intensifying screens at $-80^{\circ} \mathrm{C}$. The apparent molecular mass and $\mathrm{pI}$ of polypeptides were estimated $(n=50)$ from their migration in the gel in relation to that of standard proteins with known molecular mass (Pharmacia, St. Quentin en Yvelines, France) and isoelectric point (Bio-Rad 2D standards, Ivry-sur-Seine, France).

\section{Immunochemistry.}

Polyclonal antibodies against $\mathrm{SRAP}_{32 \mathrm{~d}}$ excised from 70 2Dpolyacrylamide gels of cell walls of $P$. tinctorius 441 were produced in rabbits by Eurogentec (Seraing, Belgium). Western blot analysis of $\mathrm{SRAP}_{32 \mathrm{~d}}$-related proteins was carried out with either anti-SRAP ${ }_{32 \mathrm{~d}}$ immunserum or a pre-immunserum according to the Immun-Blot Alkaline Phosphatase Assay kit (Bio-Rad, Ivry-sur-Seine, France). Glycan identification of CWP separated by 2D-PAGE was carried out according to the manufacturer's specifications (DIG Glycan Differentiation Kit no. 1210238, Boehringer Mannheim Biochemica, Mannheim, Germany).

IIF and immunogold EM were carried out on both 4-day-old (primary roots) ectomycorrhizas produced by the cellophaneover-agar method in a horizontal petri dish (Malajczuk et al. 1990) and 15-day-old (lateral roots) ectomycorrhizas produced by the cellophane-over-agar method in a vertical petri dish (Burgess et al. 1996). IIF labeling and immunogold EM was performed according to Balestrini et al. (1996) on semi-thin and thin sections, respectively. They were washed with 50 $\mathrm{mM}$ phosphate-buffered saline (PBS) $\mathrm{pH} 7.2$, saturated $1 \mathrm{~h}$ with $1 \%(\mathrm{wt} / \mathrm{vol})$ bovine serum albumin (BSA) in the same buffer, treated with the primary antibody overnight at $4{ }^{\circ} \mathrm{C}$, and then washed with PBS. The anti-rabbit secondary antibody was FITC (fluorescein isothiocyanate)-conjugated and used at the recommended dilution for IIF (Sigma, St. Quentin Fallavier, France). The secondary antibody for immunogold EM was the colloidal gold-goat anti-rabbit immunoglobulin complex (Bio Cell, Cardiff, UK). Gold particles were $15 \mathrm{~nm}$.

\section{Peptide mapping and sequencing.}

The $\mathrm{SRAP}_{31}$ and $\mathrm{SRAP}_{32}$ isopolypeptides were excised from 2D-PAGE, loaded on the top of a 1D-SDS polyacrylamide gels together with $15 \mu$ l of V8 protease (Sigma, P-2922) solution $(30 \mu \mathrm{g} / \mathrm{ml})$ (Cleveland et al. 1977). Gels were then silver stained. For sequencing, $\mathrm{SRAP}_{32 \mathrm{~d}}$ was excised from 70 2D polyacrylamide gels, pooled, separated by 1D-SDS-PAGE, and then electroblotted onto polyvinylidene difluoride (PVDF) membranes. Membrane in situ trypsin cleavage, peptide separation by reversed-phase HPLC, and sequence analysis were carried out as described by Bauw et al. (1989).

\section{SSH and library screening.}

Doubled-stranded cDNAs corresponding to mRNAs expressed in E. globulus $-P$. tinctorius ectomycorrhizas after 4 days of contact (tester probe), and cDNAs from E. globulus roots and $P$. tinctorius free-living mycelium were separately obtained with the SMART-PCR cDNA Synthesis kit (Clontech, Palo Alto, CA). The cDNAs from noninoculated roots and free-living mycelium were pooled (driver probe) by taking into account the respective concentrations of plant and fungal RNAs in the symbiotic tissues (35/65, vol/vol) (Carnero Diaz et al. 1997). The tester cDNA pool was subtracted twice by the mixed-driver probe (SSH; Diatchenko et al. 1996) following the manufacturer's instructions (Clontech PCR-Select cDNA Subtraction kit). An aliquot of about 150 ng of these subtracted cDNAs was labeled with digoxigenin by random priming and used for the screening of a cDNA library prepared in $\lambda$ gt11 vector from mRNA of $E$. globulus $-P$. tinctorius ectomycorrhizas (Martin and Voiblet 1998). The hybridization was performed at $65^{\circ} \mathrm{C}$ in $5 \times \mathrm{SSC}(1 \times \mathrm{SSC}$ is $0.15 \mathrm{M} \mathrm{NaCl}$ plus $0.015 \mathrm{M}$ sodium citrate) ("Standard Hybridization Buffer" of the DIG High Prime DNA Labeling kit from Boehringer-Mannheim, Mannheim, Germany) and the last wash was performed at $68^{\circ} \mathrm{C}$ in $0.5 \times \mathrm{SSC}$ containing $0.1 \%$ (wt/vol) SDS. About $2 \%$ of the $\lambda \mathrm{gt} 11 \mathrm{cDNAs}$ hybridized to the subtracted probe and 56 were characterized by single pass partial sequencing (C. Voiblet and F. Martin, unpublished results).

Six cDNA inserts showing sequence similarity with the SRAP $_{32 \mathrm{~d}}$ oligopeptides were subcloned in pBluescript II SK ${ }^{-}$ and sequenced for both strands with an automated ABI 310 sequencer (Applied Biosystems, Foster City, CA). These cDNA sequences have been deposited in the NCBI data base (GenBank accession numbers AF035678, AF124722, AF124723, and AF124724). Searches for sequence similarity in the NCBI data bases were carried out by the BLAST (Altschul et al. 1997) on-line network service.

\section{Purification of RNA and RNA gel-blot analysis.}

Total RNA was purified from noninoculated roots, freeliving mycelium, or ectomycorrhizas by the guanidinium/ phenol/SDS method of Logemann et al. (1987). Northern (RNA) blot analysis was carried out as described in Carnero 
Diaz et al. (1996). Briefly, $10 \mu \mathrm{g}$ of total RNAs was loaded in a $1.2 \%(\mathrm{wt} / \mathrm{vol})$ agarose gel in denaturing conditions, blotted onto a Hybond-N filter (Amersham, Les Ulis, France) and hybridized with the PtSRAP32 cDNA labeled with ${ }^{32} \mathrm{P}-\mathrm{dCTP}$ by random priming. The more stringent wash was performed at $65^{\circ} \mathrm{C}$ in $0.5 \times \mathrm{SSC}$ and $0.1 \%$ (wt/vol) SDS (Sambrook et al. 1989). The filter was then dehybridized and probed with the $P$. tinctorius 5.8S rDNA to estimate the level of total fungal RNA loaded in each lane (Carnero Diaz et al. 1997).

\section{ACKNOWLEDGMENTS}

This work was supported by research grants from the EurekaEurosilva program ("Changes in Gene Expression During Ectomycorrhiza Differentiation and Function") and the Groupement de Recherches et d'Etude des Génomes. P. L. and C. V. were each supported by a Doctoral Scholarship from the Ministère de l'Enseignement Supérieur et de la Recherche and D. C. was financed by scholarships of the Brasilian Governement and INRA. U. N. was supported by Postdoctoral Fellowships from the Ministère de l'Enseignement et de la Recherche and the Deutsche Forschungsgemeinschaft. We would like to thank Christine Delaruelle and Béatrice Palin (Microbiologie Forestière, I.N.R.A.-Nancy) for technical assistance, Frédéric Lapeyrie (Microbiologie Forestière, I.N.R.A.-Nancy), Treena Burgess, and Bernie Dell (Murdoch University, Murdoch, WA) for stimulating discussions, and Vincent Boiffin for his assistance in the immunolocalization assays.

\section{LITERATURE CITED}

Altschul, S. F., Madden, T. L., Schäffer, A. A., Zhang, J., Zhang, Z., Miller, W., and Lipman, D. J. 1997. Gapped BLAST and PSI-BLAST: A new generation of protein database search programs. Nucleic Acids Res. 25:3398-3402.

Balestrini, R., Hahn, M., Faccio, A., Mendgen, K., and Bonfante, P. 1996. Differential localization of carbohydrate epitopes in plant cell walls in the presence and absence of arbuscular mycorrhizal fungi. Plant Physiol. 111:203-213.

Bauw, G., Van Damme, J., Vandekerckhove, J., Gesser, B., Ratz, G., Lauridsen, J. B., and Celis, J. E. 1989. Protein-electroblotting and microsequencing strategies in generating protein data bases from twodimensional gels. Proc. Nat. Acad. Sci. USA 86:7701-7705.

Burgess, T., Dell, B., and Malajczuk, N. 1996. In vitro synthesis of Pisolithus-Eucalyptus ectomycorrhizae: synchronization of lateral tip emergence and ectomycorrhizal development. Mycorrhiza 6:189-196.

Burgess, T., Laurent, P., Dell, B., Malajczuk, N., and Martin, F. 1995. Effect of the fungal isolate aggressivity on the biosynthesis of symbiosis-related polypeptides in differentiating eucalypt ectomycorrhiza. Planta 195:408-417.

Canut, H., Carrasco, A., Galaud, J. P., Cassan, C., Bouyssou, H., Vita, N., Ferrara, P., and Pont-Lezica, R. 1998. High affinity RGD-binding sites at the plasma membrane of Arabidopsis thaliana links the cell wall. Plant J. 16:63-71.

Carnero Diaz, E., Martin, F., and Tagu, D. 1996. Eucalypt $\alpha$-tubulin: cDNA cloning and increased level of transcripts in ectomycorrhizal root system. Plant Mol. Biol. 3:905-910.

Carnero Diaz, E., Tagu, D., and Martin, F. 1997. Ribosomal DNA internal transcribed spacers to estimate the proportion of Pisolithus tinctorius and Eucalyptus globulus RNAs in ectomycorrhiza. Appl. Environ. Microbiol. 63:840-843.

Chaffin, W. L., Lopez-Ribot, J. L., Casanova, M., Gozalbo, D., and Martinez, J. P. 1998. Cell wall and secreted proteins of Candida albicans: Identification, function, and expression. Microbiol. Mol. Biol. Rev. 62:130-180.

Cleveland, D. W., Fischer, S. G., Kirschner, M. W., and Laemmli, U. K. 1977. Peptide mapping by limited proteolysis in sodium dodecyl sulfate and analysis by gel electrophoresis. J. Biol. Chem. 252:11021106.

Corrêa, A., Staples, R. C., and Hoch, H. C. 1996. Inhibition of thigmostimulated cell differentiation with RGD-peptides in Uromyces germlings. Protoplasma 194:91-102.
Dean, R. A. 1997. Signal pathways and appressorium morphogenesis. Annu. Rev. Phytopathol. 35:211-234.

Dexheimer, J., and Pargney, J. C. 1991. Comparative anatomy of the host-fungus interface in mycorrhizas. Experientia 47:312-320.

Diatchenko, L., Lau, Y. F. C., Campbell, A. C., Chenchik, A., Moqadam, F., Huang, B., Lukyanov, S., Lukyanov, K., Gurskaya, N., Sverdlov, E. D., and Siebert, P. D. 1996. Suppression subtractive hybridization: A method for generating differentially regulated or tissue-specific cDNA probes and libraries. Proc. Natl. Acad. Sci. USA 93:6025-6030.

Faik, A., Labouré, A. M., Gulino, D., Mandaron, P., and Falconet, D. 1998. A plant surface protein sharing structural properties with animal integrins. Eur. J. Biochem. 253:552-559.

Gumbiner, B. M. 1996. Cell adhesion: The molecular basis of tissue architecture and morphogenesis. Cell 84:345-357.

Hilbert, J. L., Costa, G., and Martin, F. 1991. Ectomycorrhizin synthesis and polypeptide changes during the early stage of eucalypt mycorrhiza development. Plant Physiol. 97:977-984.

Jones, E. B. G. 1994. Fungal adhesion. Mycol. Res. 98:961-981.

Kershaw, K. J., and Talbot, N. J. 1998. Hydrophobins and repellents: Proteins with fundamental roles in fungal morphogenesis. Fungal Genet. Biol. 23:18-33.

Kondoh, O., Muto, A., Kajiwara, S., Takagi, J., Saito, Y., and Shishido, K. 1995. Fruiting body-specific cDNA, $m f b A c$, from the mushroom Lentinus edodes encodes a high-molecular-weight cell-adhesion protein containing an Arg-Gly-Asp motif. Gene 154:31-37.

Laemmli, U. K. 1970. Cleavage of structural proteins during the assembly of the head of bacteriophage T4. Nature 227:680-684.

Laurent, P. 1995. Contribution à l'étude des protéines régulées par la symbiose chez l'ectomycorhize d'Eucalyptus - Pisolithus. Caractérisation de mannoprotéines pariétales chez le basidiomycète Pisolithus tinctorius. Ph.D. thesis. University Henri Poincaré - Nancy I, Nancy, France.

Logemann, J., Schell, J., and Willmitzer, L. 1987. Improved method for the isolation of RNA from plant tissues. Anal. Biochem. 163:16-20.

Malajczuk, N., Garbaye, J., and Lapeyrie, F. 1990. Infectivity of pine and eucalypt isolates of Pisolithus tinctorius on roots of Eucalyptus urophylla in vitro. 1. Mycorrhiza formation in model systems. New Phytol. 114:627-631.

Martin F., Lapeyrie, F., and Tagu, D. 1997. Altered gene expression during ectomycorrhiza development. Pages 223-242 in: The Mycota. Vol. VI: Plant Relationships. P. Tudzynski and G. Caroll, eds. Springer-Verlag, Berlin.

Martin, F., Laurent, P., De Carvalho, D., Voiblet, C., Balestrini, R., Bonfante, P., and Tagu, D. Cell wall proteins of the ectomycorrhizal basidiomycete Pisolithus tinctorius: Identification, function, and expression in symbiosis. Fungal Gen. Biol. (In press.)

Martin, F., and Voiblet, C. 1998. Large-scale sequencing of anonymous ectomycorrhiza cDNA clones. Pages 475-493 in: Mycorrhiza Manual. A. Varma, ed. Springer-Verlag, Berlin.

Mendgen, K., and Deising, H. 1993. Infection structures of fungal plant pathogens - a cytological and physiological evaluation. New Phytol. 124:193-213.

O'Farrell, P. 1975. High resolution two-dimensional electrophoresis of proteins. J. Biol. Chem. 250:4007-4021.

Peterson, R. L., and Bonfante, P. 1994. Comparative structure of vesicular-arbuscular mycorrhizas and ectomycorrhizas. Plant Soil 159: 79-88.

Ruiz-Herrera, J., Mormeneo, S., Vanaclocha, P., Font-De-Mora, J., Iranzo, M., Puertes, I., and Sentandreu, R. 1994. Structural organization of the components of the cell wall from Candida albicans. Microbiology 140:1513-1523.

Ruoslahti, E. 1996. RGD and other recognition sequences for integrins. Annu. Rev. Cell Dev. Biol. 12:697-715.

Salzer, P., Hebe, G., and Hager, A. 1997. Cleavage of chitinous elicitors from the ectomycorrhizal fungus Hebeloma crustuliniforme by host chitinases prevents induction of $\mathrm{K}^{+}$and $\mathrm{Cl}^{-}$release, extracellular alkalinization and $\mathrm{H}_{2} \mathrm{O}_{2}$ synthesis of Picea abies cells. Planta 203:470479.

Sambrook, J., Fritsch, E. F. and Maniatis, T. A. 1989. Molecular Cloning: A Laboratory Manual. 2nd ed. Cold Spring Harbor Laboratory, Cold Spring Harbor, NY.

Tagu D., Kottke, I., and Martin, F. 1998. Hydrophobins in ectomycorrhizal symbiosis: Hypothesis. Symbiosis 25:5-18.

Tagu D., and Martin, F. 1996. Molecular analysis of cell wall proteins 
expressed during the early steps of ectomycorrhiza development. New Phytol. 133:73-85.

Tagu, D., Nasse, B., and Martin, F. 1996. Cloning and characterization of hydrophobins-encoding cDNAs from the ectomycorrhizal basidiomycete Pisolithus tinctorius. Gene 168:93-97.

Takenaka, S., and Kawasaki, S. 1994. Characterization of alanine-rich, hydroxyproline-containing cell wall proteins and their application for identifying Pythium species. Physiol. Mol. Plant Pathol. 45:249-261

Wessels, J. G. H., De Vries, O. M. H., Asgeirsdottirs, A., and Schuren, F. H. J. 1991. Hydrophobin genes involved in formation of aerial hyphae and fruit bodies in Schizophyllum. Plant Cell 3:793-799.

Yasuda, T., Ishihara, H., Amano, H., and Shishido, K. 1997. Generation of basidiomycetous hyphal cell-aggregates by addition of the ArgGly-Asp motif-containing fragment of high-molecular-weight celladhesion protein MFBA derived from the basidiomycete Lentinus edodes. Biosci. Biotechnol. Biochem. 61:1587-1589.

Yasuda, T., and Shishido, K. 1997. Aggregation of yeast cells induced by the Arg-Gly-Asp motif-containing fragment of high-molecularmass cell-adhesion protein MFBA, derived from the basidiomycete mushroom Lentinus edodes. FEMS Microbiol. Lett. 154:195-200. 